This item was submitted to Loughborough's Research Repository by the author.

Items in Figshare are protected by copyright, with all rights reserved, unless otherwise indicated.

\title{
Abolishing youth justice systems: children first, offenders nowhere
}

PLEASE CITE THE PUBLISHED VERSION

https://doi.org/10.1177/1473225419898754

PUBLISHER

SAGE Publications

\section{VERSION}

AM (Accepted Manuscript)

\section{PUBLISHER STATEMENT}

This paper was accepted for publication in the journal Youth Justice and the definitive published version is available at https://doi.org/10.1177/1473225419898754. Users who receive access to an article through a repository are reminded that the article is protected by copyright and reuse is restricted to non-commercial and no derivative uses. Users may also download and save a local copy of an article accessed in an institutional repository for the user's personal reference.

\section{LICENCE}

CC BY-NC-ND 4.0

\section{REPOSITORY RECORD}

Case, Stephen, and Kevin Haines. 2020. "Abolishing Youth Justice Systems: Children First, Offenders Nowhere”. Loughborough University. https://hdl.handle.net/2134/13234352.v1. 


\section{Abolishing youth justice systems: Children first, offenders nowhere}

'The current system for dealing with youth crime is inefficient and expensive... The present arrangements are failing young people' (Audit Commission 1996: 96)

The above quotation is as true today as it was over two decades ago. The Youth Justice System in England and Wales continues to be inefficient, expensive and strikingly ineffective. The justice system is failing, even harming, children and it is failing society: the time has come to abolish justice system-based responses to childhood behaviour. In this paper, we set out arguments and evidence for the abolition of the Youth Justice System (YJS) and its responses to the behaviour of the children. Youth justice systems are historically expensive, harmful and ineffective. It is time to revisit the case for abolitionism within the youth justice field, a case thus far largely restricted to advocating for the abolition of custody for children ${ }^{1}$ who offend. Accordingly, readers may find the arguments set out in this paper challenging. Indeed, it is our intention to be deliberately provocative in order to stimulate debate in this area. We offer a more ambitious and contentious argument that the entire youth justice system should be abolished, from its underpinning principle of enacting 'justice' through punishment, to the youth courts delivering punitive sentences founded in these 'justice' principles, to the organisational structures of youth justice created to manage these sentences. Although we tend to illustrate our arguments with reference to the YJS of England and Wales (the context we are most familiar with and have worked within), we contend that these arguments have applicability to and wider implications for a range of predominantly Westernised jurisdictions. In particular, we ask why persist with a failing project, especially in light of more compelling alternatives such as the diversionary Bureau process and contemporary delivery models underpinned by 'Children First' principles? System abolition and associated non-criminal responses should be underpinned by the widespread decriminalisation of offending behaviour by children - the abolition of the construct of offending.

\section{The social construction of youth justice systems: A 200-year trajectory of criminalisation}

Systems of youth justice internationally can be understood as social constructions - the creations, artefacts and outcomes of interacting pressures exerted historically, culturally, socio-economically, academically/empirically and in the contexts of policy-making, politics, practice, media and public opinion (Case 2018). As such, youth justice systems are inherently dynamic, contingent and contested; they can be reconstructed, revised and abolished through the same pressures and interactions that create them. Since the creation of bespoke, differentiated systems of youth justice in the industrialised Western world and throughout their various incarnations, there has been vociferous debate as to their suitability, impact and effectiveness. There has been long-standing critique of youth justice systems as iatrogenic and counter-productive - as harming the children who enter them through excessive punitiveness and by actively exacerbating the very circumstances they seek to address through responses that are disproportionate to the child's offending in type, severity and duration (Hopkins-Burke 2016). Relatedly, youth justice systems have been notoriously

\footnotetext{
${ }^{1}$ According to the United Nations Convention on the Rights of the Child, any individual up to the age of 18years-old (UNCRC 1989).
} 
expensive - costly in terms of finances, resources, practitioner time and the outcomes experienced by the children exposed to them. Compounding these human, socio-economic and practical costs, youth justice processes have been alarmingly ineffective in reducing the duration and intensity of children's (iatrogenic) contact with youth justice systems, in reducing re/offending rates and in reducing the numbers of children given custodial sentences. The negative excesses of youth justice measures, it has been argued, have labelled, criminalised, adulterised and responsibilised their recipients (Goldson 2018), fuelling arguments that the entire youth justice project is harmful, inappropriate, unnecessary and should be abolished.

In a sense, the socio-historic construction of 'youth justice' was founded in an abolitionist perspective - the desire to abolish the systemic adulterisation of children in conflict with the law. However, the post-industrial social construction of 'childhood' as a period of innocence and vulnerability necessitating care and protection, introduced conflict and ambivalence regarding how these same children could be understood as threatening/dangerous when they offended (Hendrick 2015). The academic construction of 'adolescence' (Hall 1904) afforded youth justice stakeholders across the industrialised Western world a convenient means of reconciling this paradox by understanding younger children as innocent and vulnerable, thus necessitating care and welfare-based responses, whilst understanding equivalent behaviour by older children/adolescents (aka 'youths' or 'juveniles) as threatening and dangerous, thus necessitating punitive, justice-based responses (Case 2018). Social constructions of childhood and adolescence/youth motivated differentiated criminal justice responses to children's offending, which were not to be situated within a comprehensive, coordinated system for at least another 150 years. Rather, the emerging social construction of 'youth justice' was constituted by a patchwork of bespoke laws (e.g. status offences), legislation (e.g. the Youthful Offenders Act 1854 and Children Act 1908 in the United Kingdom/UK), structures (e.g. the $19^{\text {th }}$ century creation of child-only prisons and reformatory schools, the early $20^{\text {th }}$ century creation of youth courts - all across the UK, USA and Australia) and strategies underpinned by an ongoing care versus control debate ${ }^{2}$ focused in the Western world (Smith 2014). As punishment and treatment logics battled for supremacy as the primary shapers of youth justice practice, so emerged bifurcation - the strategy of polarising official responses to offending by children based on both seriousness and age. Bifurcation represented a twin-track (bifurcated) approach to punishing serious offending (typically through custody), whilst implementing more lenient responses to less serious offences (e.g. diversion from formal sentencing processes). The growing popularity of bifurcation, however, was indicative of a continued systemic commitment to the use of custody for children who offended. Accordingly, the abolitionist arguments (generated primarily in the USA and UK contexts) that gained significant traction in the 1970s and 80s focused predominantly on the abolition of, and alternatives to, custody for children. Abolitionists assert that the 'escalatory' trend in child custody across the $20^{\text {th }}$ century (Fionda 2005: 164) was of particular concern because 'the incarceration of children has proved to be spectacularly ineffective for many years' (Gavin 2014: 37; see also Goldson and Jamieson 2002; Nacro 2003). Conversely, intermediate treatment in the 1970s and diversion in the $1980 \mathrm{~s}$ have characterised a 'successful revolution' in youth justice (Allen 1991); a progressive movement towards abolishing key aspects of formal system contact.

\footnotetext{
2 The much-rehearsed 'welfare versus justice debate' (see Smith 2005), widely understood as characterising youth justice throughout the late 19th and entire 20th centuries was, in reality, quite short lived - confined to a period from the mid-1970s to the early 1990s (Haines and Drakeford 1998). A comprehensive history of juvenile/youth justice in England and Wales is far more complex and nuanced than a simple welfare vs justice dichotomy - it is also a history well outwith the scope of this paper.
} 


\section{From abolitionism to expansionism}

Indicative of the dynamic and constructed nature of youth justice (systems), the tentative, implicitly abolitionist tendencies of the 1980s diversionary project were swept away by a wave of expansionism in the 1990s. A burgeoning 'punitive turn' in youth justice (Muncie 2008) legitimised and accelerated the expansion of the youth justice project throughout the industrialised Western world. Throughout the 1990s, an increasing number of nation states sought to coalesce their existing array of youth justice responses into formalised systems in order to address the politically-constructed 'youth crime problem'. Moreover, the perceived lack of effectiveness of traditional welfare-and justice-based responses underpinned calls for increasing punitiveness and a fresh, (cost) effective approach to youth justice within these new formal and official systems. In the dual contexts of new public management (Andrews and Van de Walle 2013) and burgeoning neo-liberalism (Muncie 2014), formative youth justice systems across the Western world (most notably in the UK, North America and Australasia) have been shaped by modernising and pragmatic logics, evidenced by system expansionism (Wacquant 2009), both vertical (e.g. accelerating custody rates) and horizontal (e.g. increased regulatory control and surveillance of 'problem' populations), often driven by managerialist, performance-led processes and neo-correctionalist, risk-led practices (Case and Haines 2018).

The punitive turn-inspired, modernising pragmatism of the 'new youth justice' in England and Wales (Goldson 2000) provides a state-specific example of the alarmingly ineffective and harmful (to children) effects of expansionism in international youth justice, simultaneously illustrating a series of strategic and practical regressive steps that reinforce abolitionist arguments. In the decade that followed the Crime and Disorder Act 1998 in England and Wales, 'new youth justice' strategies of responsibilisation and early intervention(ism) exerted a significant influence on youth justice processes and outcomes in England and Wales. Notably, the new 'prevention' priority for the YJS was animated by the Risk Factor Prevention Paradigm/RFPP (see Farrington 2000) and a proliferation of new, bespoke laws, sentences, structures and strategies, the (arguably unintended) corollaries of which were overwhelmingly criminalising - net-widening, interventionism and the conflation of children and adolescents into the catchall category of 'youth offender' (Goldson 2014). Crucially, however, these iatrogenic developments were not limited to the England and Wales context and have been reflected internationally, for example, in the USA (Goshe 2019; Goddard and Myers 2017; Feld and Bishop 2011), Australasia (Hemphill, Heerde and Schole-Balog 2016) and elsewhere across the western world (Case and Haines 2018), although explicitly-resisted in other regions (e.g. Nordic countries - Lappi-Sepalla, in Goldson 2018).

Turning once again to our main exemplar, across the YJS of England and Wales, a 45\% increase in spending and a concurrent increase in youth justice activities throughout this decade of disaster had 'no measurable impact' on self-reported offending by children, increased the number of First-Time Entrants (FTEs) into the system, increased reoffending rates and the use of custody: which actually increased by $8 \%$ over the decade (Solomon and Garside 2008). Compounding this spectacular failure to meet government targets for effectiveness, the 'new' YJS also failed to meet needs-related targets for accommodation, employment, training and employment, substance use and mental health (Solomon and Garside 2008; see also Case 2018). Furthermore, by the end of the decade, the systemdefining RFPP, applied in practice via the 'Scaled Approach' to assessment and intervention 
was on the verge of abolition due to its criminalising, interventionist tendencies and its ineffectiveness in reducing reoffending (Haines and Case 2012; Sutherland 2009; see also YJB 2013).

At the macro-systemic level, therefore, the dominant 'prevention' focus of youth justice systems across the globe (cf. Riyadh Guidelines 1990, in Case 2018) was (and remains) anathema to contact with a formal system of youth justice. When operationalised in universal terms (in line with much of the underpinning evidence-based), prevention means the avoidance of the onset of offending, rather than the prevention of reoffending - better conceptualised as the reduction of offending. Preventing offending and its sister project of early intervention with children 'at risk' of offending clearly have no place within a system dealing with identified 'offenders'. For example, early intervention is intended to identify and work with children considered 'at risk' of offending before it starts and as such, can constitute a form of prevention. Logically, therefore, early intervention (not to mention prevention and diversion, is not feasible with identified/convicted child 'offenders'. Both prevention and early intervention objectives are much better served by other (integrated) childcare and support systems in order to address unmet needs (e.g. familial, educational, mental health, health, accommodation, training and employment-based), existing socio-structural disadvantages and iatrogenic system contact escalating into offending behaviour. Counterintuitively, the socalled 'effective' practice visited upon children in youth justice systems internationally, notably in England and Wales (i.e. children who have not been diverted from the formal system or prevented from offending) is increasingly unfit for purpose, characterised by a stubborn adherence to the criminalising interventionism and net-widening (see Hampson 2017; MOJ 2016). Consequently, the expansionist zeal of the punitive turn has been ineffective (systemically) and actively harmful (individually) by drawing increasing numbers of children into the formal system, labelling them as 'risky' and visiting (often punitive) interventions upon them in order to serve a negative, deficit-based objectives of the risk prevention agenda.

\section{From expansionism to pragmatic reductionism}

A strong case can be made for economic austerity having precipitated a period of tentative, strategic abolitionism across predominantly Westernised youth justice systems (akin to abolition by stealth) due to the dramatic reduction of and disinvestment in formal youth justice apparatus and mechanisms (e.g. across the European Union - Bell, in Goldson 2018; across the USA - Congressional Research Service 2019). For example, the expansionist and reformist fervour of the 'new youth justice' in England and Wales came to a shuddering halt with the 2010 change of UK government during the onset of sweeping economic austerity, evidenced by a substantial reduction of youth justice budgets and retraction of services. The YJB's annual budget fell by $72 \%$ from $£ 452.3$ million in $2010 / 11$ to £126.6 million in 2017/18 (YJB 2018a). There has been an associated reduction in the size of the YJS, with annual decreases in the number of children offending, being arrested, entering the system for the first-time, reoffending and given custodial sentences - diminishing returns motivated more by economic and political pragmatism than by any principled or evidential change of heart by decision-makers regarding how to respond to children's offending (Smith 2016; Bateman 2017). Contemporaneously, the size and number of youth justice structures has diminished due to swingeing budgetary cuts. To put the impact of economic austerity into perspective, spending on the secure estate ${ }^{3}$ in $2017 / 18$ ( $£ 54.8$ million) was $£ 214.1$ million

\footnotetext{
${ }^{3}$ Young Offender Institutions, Secure Training Centres and Secure Children's Homes.
} 
lower than at the end of the 'bulimic' (Goldson 2018) expansionist era of youth justice in 2010/11 (£268.9 million).

In the context of economic austerity and its associated drive for localised pragmatism and innovation, contemporary youth justice developments post-2010 have indicated an increasingly progressive mind-set amongst policy-makers and even hint at the notion of abolishing non-custodial elements of the YJS. Notable developments include the radical diversionary emphasis of the Legal Aid Sentencing and Punishment of Offenders (LASPO) Act 2012 and the growing popularity of non-criminalising, 'Children First' approaches to policing (NPCC 2015), court sentencing (Sentencing Council 2017) and the delivery of youth justice more broadly (YJB 2019). In terms of the reduction of FTEs 'key performance indicator' for youth offending teams in the YJS (the other main Key Performance Indicators (KPIs) being reduction of reoffending and reduction of custody), a new out-of-court diversion system introduced in 2012 (LASPO 2012) now promotes more flexible and diversionary approaches to low-level offending by children. This 'progressive' reversion to a previously successful youth justice strategy from the 1980s sustains arguments to abolish formal youth justice processing for less serious offences; arguments supported by evidence of significant success in terms of an 85\% reduction in FTEs in the decade 2007/8-2016/17 (MoJ and YJB 2018) and a further 14\% fall from 2017-18 (MoJ and YJB 2019).

Long-term success in reducing FTEs in England and Wales, however, has exerted an ironic knock-on effect upon the reduction of reoffending KPI. Although fewer children now enter the system, those who remain represent a smaller, yet more troubled cohort, disproportionately presenting with multiple complex needs and adverse childhood experiences that have been largely unaddressed by other childcare systems (Johns, Williams and Haines 2017). These are the children most likely to be suffering from the effects of restricted agency, trauma, so-called 'adverse childhood experiences', brain injury and/or lack of neurological development (YJB and MoJ 2017; Taylor et al 2014), so the very children most likely to be stuck 'in the moment' when they offend (Haines et al, in press). This more problematic nature of the contemporary cohort remaining in the YJS has been reflected in annual increases in reoffending 'rates', ${ }^{5}$ which the continued hangover from the Scaled Approach has been unable (and unfit) to mitigate. Consequently, although the 'number' of children reoffending has consistently fallen each year from 2007/8-2016/17, amounting to a $79 \%$ decrease in reoffending numbers (YJB and MoJ 2018), that same decade evidenced a $4 \%$ increase in reoffending rates.

Despite ostensible success in reducing FTEs and more restricted success in tackling reoffending in England and Wales, custodial sentencing remains a particularly stubborn and debilitating trait of youth justice systems across the world (cf. Congressional Research Service 2019) ; particularly those focused on preventing offending over not punishing offending or harming children who offend. Critically, custody has been identified as wholly

\footnotetext{
${ }^{4}$ This was the year that the police 'offences brought to justice' target was abolished (Flanagan 2008). Arrests of children have decreased annually since that time (YJB and MoJ 2018), largely due to a change in policing culture precipitated by the abolition of this performance indicator/target and at least in part due to the subsequent inception of a 'child centred policing strategy' (NPCC 2015) that seeks to actively avoid the criminalisation of children (see also Case 2018).

${ }^{5}$ Since 2017, reoffending rates have been calculated as a weighted average across four identified cohorts of children in the YJS each year, with each cohort covering a three-month period (YJB and MoJ 2017). An equivalent argument regarding falling numbers but rising rates can be applied to the recent increase in custody rates (measured as custody per 1000 of the offending population), when compared to the decreasing numbers of children in custody over the past decade (YJB and MoJ 2018, 2019).
} 
ineffective - exerting minimum to no impact on reducing reoffending (Gavin 2014) and even potentially increasing the risk of reoffending (McAra and McVie 2015; NACRO 2010). The use of custody with children has been widely vilified as unnecessary, harmful, expensive, disproportionate and ineffective (Case 2018; Bateman 2017). Its continued use ${ }^{6}$ contravenes Article $37 \mathrm{~b}$ of the United Nations Convention on the Rights of the Child (UNCRC), that "detention or imprisonment of the child should only be used as a "last resort" (UNCRC 1989). Further to this, the bullying, racism, violence, lack of health and psychiatric care, selfharming and suicide that characterise young offender institutions in England and Wales (Gavin 2014) contravenes Article 37c of the UNCRC, namely that 'every child deprived of liberty should be treated with humanity and respect' (UNCRC 1989). As if these criticisms were not enough to support Children First, decarcerative and abolitionist arguments, custody of children has been found to compound pre-existing disadvantages, to exacerbate broken links with family and social networks and to cut off opportunities for reparation (Muncie 2014). The contemporary context of youth justice is one wherein custodial sentencing remains stubbornly high, reoffending following custody (as evidence of system effectiveness) remains stubbornly high, support for diversion (from government- to ground-level) has rarely been so high, actual diversion rates have really been so high and offending/reoffending so low, yet any sense of a coherent approach to responding to the behaviour of children remains low. This conflict and ambivalence has been animated by competing and conflicting drivers and a vacuum in understandings of children and the nature of childhood. Consequently, the case for abolishing custody remains highly convincing.

\section{Tentative moves towards abolitionism}

Despite significant system contraction in structural and financial terms, contemporary youth justice systems across the industrialised Western world remain costly, with personal costs experienced by a (decreasing) cohort of children who remain in the formal system and socioeconomic costs stemming from the continued reoffending by, and incarceration of, this cohort of children (Bell, in Goldson 2018). The rebirth of diversion away from formal systems internationally (cf. McAra and McVie, in Goldson 2018) has gone some way to addressing the long-accepted view that much offending by children is relatively trivial and transitory. Contemporary reductions in custodial budgets further indicate a diminishing faith in traditional youth justice responses. The current impression is of an international movement approximating 'abolition by stealth' - continued disinvestment in youth justice structures and processes for economic and pragmatic reasons, without subsequent reinvestment in children experiencing problems that would previously brought into contact with the formal YJS (cf. Goldson 2018). Arguably, therefore, economic austerity has encouraged a political focus on ameliorating socio-economic costs, without sufficient focus and emphasis upon the personal costs are experienced by children (Bateman 2018). Notwithstanding the economic rationale for a movement towards abolitionism, it is becoming clear that the step towards formal abolition of the YJS is ever smaller, more feasible and increasingly supported by formal criminal justice and government agencies. Consequently, the YJB and others appear to be making the case for abolition (by stealth) already - we are seeking to take this case to its logical conclusion.

\footnotetext{
${ }^{6}$ It must be acknowledged, however, that present day custodial spend in the YJS is falling - decreasing by $£ 70.7$ million between 2016/17 (when it constituted 60\% of the total YJB budget) and 2017/18 (when it was 43\% of the total budget). Therefore, there are tentative indications of a move away from the commitment to custody for children, evidenced by a 69\% reduction in custodial numbers from March 2008-March 2018 and notwithstanding an anomalous pattern of monthly increases in 2017 (YJB and MoJ 2018).
} 
The government-commissioned 'Review of the Youth Justice System in England and Wales' (aka the 'Taylor Review' - Taylor 2016) offers a clear example of tentative, yet increasingly formalised support for the abolition of (at least elements of) youth justice. The author Charlie Taylor acknowledged the successful retrenchment from formal youth justice measures (i.e. reductions in FTE rates and the numbers of children reoffending at the national level), which have been premised on diversion and prevention from formal contact with the YJS. However, the review rationale was that the YJS remained ineffective in reducing reoffending. Notably, existing court sentences were perceived as unsuccessful (YJB and MoJ 2017), with evidence of high reoffending rates within one year for children receiving a Youth Rehabilitation Order $(64 \%)$ and a custodial sentence $(69 \%)$. Accordingly, the system required revision to render it fit for purpose when working with a modern cohort of children who increasingly present with multiple complex needs, mental health problems and entrenched social disadvantage (MoJ 2016). This led report author, Charlie Taylor, to question 'with fewer young people requiring youth offending services, are the current arrangements for dealing with the right ones?' (Taylor interim report 2016: 2). The final Taylor Review (Taylor 2016) made several radical recommendations for improving the YJS, most of which moved the political debate closer towards an abolitionist stance (at least implicitly) and explicitly focused on the more appropriate treatment of children when they offend. Taylor, who was subsequently assigned to the role of chair of the $\mathrm{YJB}^{7}$, strongly recommended:

- 'Children first' youth justice: the review recommended an alternative model of youth justice that responds to offending by prioritising 'the child first and the offender second' (Taylor 2016: 3). Therefore, the review sought to reconstruct the youth justice narrative by redefining 'youth offenders' as children in trouble who present with unmet needs and whose problems have manifested in offending behaviour, rather than the offending defining their identity (see Drakeford 2010);

- More diversion: existing diversionary approaches were deemed successful and worthy of consolidation, formalisation and more standardisation. Accordingly, new 'Children's Panels' were proposed, consisting of magistrates, local authority key workers and other stakeholder professionals working alongside the child and their parent/carer to decide upon appropriate youth justice responses with due consideration of welfare, health and education issues;

- Abolishing young offender institutions (YOIs): the report proposed a new form of education-focused secure institution, 'Secure Schools', to replace young offender institutions and to prioritise qualifications, skills building, knowledge development and other support services (e.g. health, mental health, speech therapy) rather than punishment. However, early aspirations for these schools to constitute a progressive break from custodial, 'secure estate' institutions appear premature following the announcement of Medway Secure Training Centre as the pilot site - an institution with notorious history of punitive, repressive and dehumanising treatment of children in custody (Medway Improvement Board 2016).

\footnotetext{
7 The non-departmental public body charged with monitoring and managing the performance of the YJS, in particular, the performance of youth offending teams (YOTs) in reducing first-time entrants into the YJS, reducing reoffending and reducing custody. The YJB also allocates funding to YOTs and provides ongoing support and guidance on effective youth justice practice (cf. Case 2018).
} 
The recommendations of the Taylor Review, with the exception of Secure Schools, were largely ignored in the lukewarm government response to the report (MoJ 2016). The overriding sense is that the current government, operating in a context of economic austerity and increasing socio-political insecurity (exacerbated by Brexit), lacks the political will, stability, focus and resources to follow through on the recommended changes to the YJS, despite having originally commissioned the review. Nevertheless, the progressive Taylor recommendations have their basis in the thorough-going critique of the systemic treatment of children who offend (much of which is reflected in this article) and serve to consolidate the case for abolishing the YJS as we know it.

\section{Children First abolitionism}

Socially-constructed systems of youth justice across the industrialised world have vacillated between conflicting agendas rooted in partial abolitionism (e.g. abolishing custody), bifurcation (e.g. diversion-punishment) and expansionism (e.g. punitive interventionism). Over this period, there is limited evidence (if any) that formal youth justice systems are 'effective' in any definition of that term. Fundamentally, the abolition of youth justice systems must start with the abolition of the term 'youth offenders': an atavistic throwback to early social constructions of the dangerous adolescent and stigmatising label that was legitimised through the 1990s punitive turn. Children who offend, including those who enter the YJS in its current forms in different international jurisdictions, must be reconstructed as 'children' and responded to as 'children first' (Taylor 2016; after Haines and Case 2015). Even the corollary of 'offenders second' should be dropped ${ }^{8}$. Offending by children (often transitory and non-serious) must be brought into its proper perspective as simply one element of a much more complex identity of the child (Drakeford 2010).

So what would a non-youth justice system look like for children who offend? First and foremost, a Children First system to replace the YJS must be child-appropriate - providing a full range of services to children. The Children First model champions a 'positive promotion' approach over the (criminal justice) emphasis on negative outcomes/behaviours. Positive promotion is grounded in principles of universalism, diversion and normalisation, pursued through (non-criminal justice) practice that is inclusionary, participatory and legitimate; it is evidenced through partnership, engagement and access to universal entitlements (see Case and Haines 2018). Accordingly, Children First services should range from the universal promotion of positive behaviours/outcomes (Haines and Case 2011) to the targeted promotion of positive behaviours/outcomes (Smith and Gray 2018) to normalising, childfocused practice (Brooks and Byrne 2015) to diversion (Kelly and Armitage 2015; Smith 2016) to individualised, targeted (not risk-based) prevention ${ }^{9}$ (Kelly 2012). Therefore, responses to all offending behaviour by children must be children first and non-criminalising. Whilst levels of child-focused support may vary based on offence seriousness and the child's individual circumstances, the fundamental Children First approach should not.

There is a cogent, growing international evidence-base attesting to the impact and effectiveness of Children First-informed responses to offending by children (e.g. 'transatlantic positive youth justice' - Case and Haines 2018; see also Goddard and Myers this issue). A large body of evidence is available from the evaluations of an iterative series of local and national prevention programmes/interventions - all underpinned by Children First

\footnotetext{
${ }^{8}$, Haines admits that when he first wrote the term (in Haines and Drakeford 1998), he was not totally happy with it but could not think of a better one at the time.

9 Although we do not favour the term 'prevention', as it is typically ill-informed, misunderstood, poorly-defined and misapplied in incongruent and ambivalent ways in youth justice (cf. Case and Haines 2015).
} 
principles of promoting positive behaviours/outcomes, diversion, engagement, legitimacy, evidence-based partnership and responsibilising adults (Case and Haines 2018; Haines and Case 2015). These Children First responses to offending by children have evolved in focus from targeting the underlying influences on problem behaviours and the barriers to achieving positive outcomes such as secondary school exclusion (the 'Promoting Positive Behaviour' programme - Haines and Case 2003) and offending by children (the 'Promoting Prevention' programme - Case and Haines 2005), to explicitly promoting prosocial, positive outcomes for children (the 'Positive Promotion Project' - Case, Charles and Haines 2012), such as successfully accessing their universal rights (cf. Haines and Case 2009; Case et al 2005). However, perhaps the most developed example of Children First principles in action is the diversionary 'Bureau' approach developed in Wales (cf. Haines et al 2013; see also Taylor 2016; Welsh Government/YJB 2014).

\section{Diversion from the formal YJS; diversion into support services}

The growing evidence-base suggests to us that children who offend should be brought into contact with diversionary panels aligned with extant successful processes in England and Wales, in particular, the Welsh 'Bureau' model. Bureau is the most effective way of responding to childhood behaviour- if the goals are to address the issues faced by children who offend, to divert children from formal youth justice processes and to prevent reoffending and reconviction (cf. Brown 2019; Case 2018; Haines et al 2013). The seminal Bureau model (bearing some resemblance to the 'Children's Panels' mooted in the Taylor Review - Taylor 2016) was established in Swansea, Wales in 2007/8. The model enables the pursuit of a series of aims compatible with a Children First and abolitionist stance, namely:

- to divert children from formal youth justice processes;

- to reduce FTEs into the YJS;

- to tackle the underlying causes of offending through positive promotion;

- to treat children who offend as 'children first'

(adapted from Haines et al 2013)

Adapting this model to guide a non-criminal justice, Children First approach would require all children who offend to be referred to the local Bureau. After this initial referral stage, a Bureau worker conducts an holistic assessment of the child (stage two), collating information from a broad range of children's services and key stakeholders in order to better understand the child circumstances, experiences and support needs. The following stage, the 'Bureau Panel', is a meeting of key stakeholder staff and trained community representatives with the purpose of proposing a non-criminal justice, multi-agency and explicitly individualised support package to promote positive behaviours and outcomes for the child. The final stage of the Children First Bureau process, the 'Bureau Clinic', consists of the child and a parent/carer/representative, plus panel members, meeting to discuss the context and circumstances of the child's life at the time of the offending behaviour, with the objective of identifying and agreeing responsive and supportive services (i.e. building on the initial Panel recommendations). Clinic decisions should be made within an engaging and legitimate (fair, equitable, transparent) partnership environment and should be child-friendly, individualised and located within a positive, promotional, prosocial and normalising (non-criminalising) model (see Haines and Case 2018).

Crucially, the Bureau model outlined has been evidenced to be highly effective in significantly reducing levels of FTEs, reoffending and custody at the local level (Haines et al 
2013), reductions that outstrip existing formal processes of youth justice and trends that have continued beyond the life of the evaluation (cf. Brown 2019; Case and Haines 2018). Qualitative evidence has identified the Children First elements of the model, notably normalisation, child-appropriate support, engagement in positive promotion, as the key mechanisms driving the effectiveness of the modelling in the experiences of key stakeholders - children and parents, as well as Bureau staff (Hoffman and MacDonald 2011; see also Smith 2016). Indeed, the Bureau demonstrated sufficient levels of sustained effectiveness and impact locally to warrant a national roll-out across all local areas in Wales (see Welsh Government/YJB 2014). Most significantly, the rate of reconviction following Bureau was lower than $10 \%$ (the next most 'effective' being Referral Orders at around $20 \%$ ), this is the most effective 'intervention' in terms of the lowest rate of reconviction of any other intervention that we are aware of world-wide. Logically, therefore, if a non-criminal disposal is the most effective method of responding to childhood behaviour then what justification is there for a formal youth justice system?

\section{Conclusion}

Critical reflection on the growing international evidence-base in youth justice indicates that contact with the formal YJS at all stages (e.g. arrest, court, assessment, intervention, custody) can be criminogenic and iatrogenic (cf. Goshe 2019; McAlister and Carr 2017). Conversely, a rapidly-expanding evidence-base in support of the 'Children First' model of youth justice consistently and cogently demonstrates that keeping children out of formal youth justice systems is the most effective response to offending behaviour. The evidence for this is England and Wales in incontrovertible. The evidence for this more widely is emerging as diversionary strategies and practice gain traction (cf. Smith 2017, 2014).

At the time of writing (November 2019), the YJB has plans to introduce 'Children First' as the guiding principle for the YJS of England and Wales, requiring 'that all youth justice services prioritise children's best interests, constructively promote their potential and desistance, encourage their active engagement and minimise the potential damage that their contact with the system can bring' (YJB 2018: 2; founded in Byrne and Case 2016; Haines and Case 2015; see also Hazel 2017). The working paper and formative revisions to National Standards guidance for youth justice practice (YJB 2018b) advocate for prevention, diversion and minimal intervention approaches that 'promote a childhood removed from the justice system' (ibid). This latter assertion clearly speaks to an abolitionist argument. Indeed, it is becoming increasingly apparent that abolitionist arguments could be pushing against an open door in the current socio-political and economic context of youth justice. The recent YJB movement towards a Children First position has been reflected in the changing nature of YOT models nationally (Smith and Gray 2018) and is compatible with arguments to abolish key elements of formal youth justice (e.g. system contact, court sentencing, custody) consolidates equivalent Children First approaches adopted by key stakeholder organisations in relation to policing (National Police Chiefs Council 2015), diversion from the YJS (LASPO 2012) and court sentencing (Sentencing Council 2017). Consequently, the step towards formal abolition of the YJS of England and Wales is arguably smaller than ever, particularly in the wider socio-economic contexts of westernised models of youth justice and in light of increasing advocacy for Children First and associated 'child-friendly' models of youth justice internationally (cf. Goshe 2019; Liefaard and Kilkelly, in Goldson 2018) and across specific international nation states (cf. USA - Goddard and Myers 2017; Australia Johns 2018). Furthermore, the guiding principles of Children First (e.g. diversion, promotion, engagement, relationship-building), along with additional principles to be found in the original model (e.g. legitimacy, evidenced-based partnership, systems management, 
responsibilising adults - Haines and Case 2015), whilst developed to inform contemporary practice within the YJS, are even more applicable in non-criminal (youth justice) systems.

The contemporary context of industrialised youth justice, illustrated most clearly in England and Wales, is characterised by the creeping abolition (by stealth) of key elements of (notoriously iatrogenic) formal systems, policies, strategies and practices of youth justice and tentative movement towards integrated, holistic, non-criminalising and non-punitive 'Children First' responses to offending. More than ever, the very notion of 'children first youth justice' presents as oxymoronic (an attempt to humanise an inhuman system), with the associated principles of 'Children First' more appropriately situated within integrated, 'whole child' systems that normalise and decriminalise offending behaviour by children - preferably systems modelled on the evidence-based and effective Bureau process. On the strength of our Children First arguments and evidence supporting the abolition of youth justice systems, we now invite those who wish to defend and promote a youth justice response to set out their case. 


\section{Bibliography}

Allen, R. (1991) Out of jail: The reduction in the use of penal custody for male juveniles 1981-1988. Howard Journal, 30(1): 30-52.

Andrews, R. and Van de Walle, S. (2013) "New Public Management and Citizens' Perceptions of Local Service Efficiency, Responsiveness, Equity and Effectiveness." Public Management Review 15 (5): 762-783.

Association of YOT Managers (2018) AYM response to YJB draft National Standards. London: YJB.

Audit Commission (1996) Misspent Youth. London: Audit Commission.

Bateman, T (2011) 'Punishing poverty: the 'scaled approach' and youth justice practice' in Howard Journal of Penal Reform 50(2): 171-183.

Bateman, T. (2017) The state of youth justice 2017: an overview of trends and developments. London: NAYJ.

Bateman, T. (2018) The state of youth justice 2018: an overview of trends and developments. London: NAYJ.

Brooks, K. and Byrne, B. (2015) Post-YOT youth justice. Howard League Working Papers, https://howardleague.org/wp-content/uploads/2016/04/HLWP_19_2015.pdf.

Burnett, R. and Appleton, K. (2004) Joined-up services to tackle youth crime. British Journal of Criminology, 44(1): 34-54.

Case, S.P. (2018) Youth Justice: A Critical introduction. Abingdon: Routledge.

Case, S.P., Clutton, S. and Haines, K.R. (2005) Extending Entitlement: A Welsh policy for children. Wales Journal of Law and Policy, 4 (2), 187-202.

Case, S.P. and Haines, K.R. (2009) Understanding youth offending: Risk factor research policy and practice. Cullompton: Willan.

Case, S.P. and Haines, K.R. (2010) Juvenile delinquency: Manifestations and causes. In: M. Herzog-Evans (ed.), Transnational Criminology Manual, Nijmegen, Wolf Legal Publishers.

Case, S.P. and Haines, K. R. (2015) Children First, Offenders Second Positive Promotion: Reframing the Prevention Debate. Youth Justice Journal, 15 (3): 226-239.

Case, S.P. and Haines, K.R. (2018) Transatlantic 'positive youth justice': Coherent movement or disparate critique? Crime Prevention and Community Safety, 20(3): 208-222.

Case, S.P. and Haines, K.R. (2019) Knife crime: Children are not the problem, they are part of the solution. https://theconversation.com/knife-crime-children-are-not-the-problem-theyare-part-of-the-solution-106893 
Case, S.P. and Haines, K.R. (in press) Assessing risks and needs in youth justice: Key challenges. In: F. McNeill and H. Graham (eds) Routledge Companion to Rehabilitative Work in Criminal Justice. Abingdon: Routledge.

Case, S.P. and Hampson, K. (2019) Youth justice pathways to change: Drivers, challenges and opportunities. Youth Justice Journal. Early view.

Congressional Research Service (2019) Juvenile Justice Funding Trends. Washington: CRS.

Drakeford, M. (2010) Devolution and youth justice in Wales. Criminology and Criminal Justice, 10(2): 137-154.

Eadie, T. and Canton, R. (2002) Practising in a Context of Ambivalence: The Challenge for Youth Justice Workers. Youth Justice Journal, 2(1): 14-26.

Farrington, D.P. (2000) 'Explaining and preventing crime: The globalization of Knowledge', Criminology, 38(1): 1-24.

Feld, B.C. and Bishop, D.M. (2011) The Oxford Handbook of Juvenile Crime and Juvenile Justice. Oxford: OUP.

Fionda, J. (2005) Devils and Angels: Youth Policy and Crime. Abingdon: Hart Publishing.

Gavin, P. (2014) No Place for Children: A Case for the Abolition of Child Imprisonment in England and Wales. Irish Journal of Applied Social Studies, Vol 14, Iss 1, Article 5 https://arrow.dit.ie/cgi/viewcontent.cgi?article=1219\&context=ijass.

Flanagan, R. (2008) The Review of Policing: Final Report, London: HMCIC.

Goddard, T. and Myers, R. (2017) Against evidence-based oppression: Marginalized youth and the politics of risk-based assessment and intervention. Theoretical Criminology, 21(2): 151-167.

Goldson, B. (2000) The New Youth Justice. Lyme Regis: Russell House.

Goldson, B. (2014). 'Youth Justice in a Changing Europe: Crisis Conditions and Alternative Visions'. Perspectives on Youth, Vol. 1: 39-52.

Goldson, B. (2018) Juvenile justice in Europe. Abingdon: Routledge.

Goldson, B. and Jamieson, J. (2002) Youth Crime, the 'Parenting Deficit' and State Intervention: A Contextual Critique. Youth Justice, 2: 82-99.

Goshe, S. (2019) How Contemporary Rehabilitation Fails Youth and Sabotages the American Juvenile Justice System: A Critique and Call for Change. Critical Criminology, Online First.

Haines, K.R. and Case, S.P. (2003) Promoting Positive Behaviour in Schools: The Youth Social Audit. Youth Justice, 3 (2), 86-103. 
Haines, K.R. and Case, S.P. (2012) Is the Scaled Approach a Failed Approach? Youth Justice, 12 (3): 212-228.

Haines, K.R. and Case, S.P. (2015) Positive Youth Justice: Children First, Offenders Second. Bristol: Policy Press.

Haines, K.R. and Case, S.P. (2018) The Future of Youth Justice. Youth Justice Journal, 18(2): 131-148.

Haines, K.R., Case, S.P., Charles, A.D. and Davies, K. (2013) The Swansea Bureau: A Model of Diversion from the Youth Justice System. International Journal of Law, Crime and Justice. Vol. 41, Issue 2: 167187.

Haines, K.R., Case, S.P., Deakin, J., Goddard, T., Gray, P., Hughes, N., Johns, D., Laidler, K.A., Richards, K., Smith, R.S., Webster, C. (in press) Children and Crime: In the Moment.

Haines, K. and Drakeford, M. (1998) Young People and Youth Justice. London: Macmillian.

Hall, G.S. (1904) Adolescence. New York: Applegate.

Hazel N (2017) “Now all I care about is my future” London: Nacro / Beyond Youth Custody,

Hemphill, S.A., Heerde, J.A. and Scholes-Balog, K.E. (2016) Risk factors and risk-based protective factors for violent offending. Journal of Criminal Justice, 45: 94-100.

Hendrick, H. (2015) Histories of Youth Crime and Youth Justice. In: B. Goldson and J. Muncie (eds) Youth Crime and Justice. London: Sage.

Hoffman, S. and Macdonald, S. (2011) Tackling Youth Anti-Social Behaviour in Devolving Wales: A Study of the Tiered Approach in Swansea', Youth Justice, 11(2): 150-167.

Hopkins-Burke, R. (2016) Young People, Crime and Justice. Abingdon: Routledge.

Johns, D. (2018) A Social Ecological Approach to 'Child-Friendly' Youth Justice. In: NAYJ (ed) Child-Friendly Justice. London: NAYJ.

Johns, D., Williams, K. and Haines, K.R. (2017) Ecological youth justice. Understanding the social ecology of young people's prolific offending. Youth Justice, 17(1): 3-21.

Kelly, L. (2012) Representing and Preventing Youth Crime and Disorder: Intended and Unintended Consequences of Targeted Youth Programmes in England. Youth Justice, 8/1: 21-37.

Kelly, L. and Armitage, V. (2015) Diverse Diversions: Youth Justice Reform, Localized Practices, and a 'New Interventionist Diversion'? Youth Justice, 15/2: 117-133.

Lee, P. (2018) Justice Minister outlines vision for Secure Schools. Press Release, June 1 ${ }^{\text {st }}$, 2018. London: MoJ. 
McAlister, S. and Carr, N. (2017) Experiencing youth justice penalty. In: A. Furlong (ed) Routledge Handbook of Youth and Young Adulthood. London: Routledge.

McAra, L. and McVie, S. (2007) 'Youth Justice? The impact of system contact on patterns of desistance from offending. European Journal of Criminology, 4(3) :315-345.

McAra, L. and McVie, S. (2015) 'The Case for Diversion and Minimum Necessary Intervention'. In: B. Goldson and J. Muncie (eds) Youth Crime and Justice, London: Sage.

Medway Improvement Board (2016) Medway Improvement Board Final Report of the Board's Advice to Secretary of State for Justice. https://assets.publishing.service.gov.uk/government/uploads/system/uploads/attachment_data /file/523167/medway-report.pdf.

Ministry of Justice (2016) The Government Response to Charlie Taylor's Review of the Youth Justice System. London: MoJ.

Muncie, J. (2008) The 'punitive' turn in juvenile justice: Cultures of control and rights compliance

Muncie, J. (2014) Youth and Crime. London: Sage.

Nacro (2003) A Failure of Justice. London, Nacro.

Nacro (2010) Reducing the number of children and young people in custody. London: Nacro.

National Police Chiefs' Council (2015) Child-centred Policing. National Strategy for the Policing of Children and Young People. London: NPCC.

Sentencing Council (2017) Sentencing Children and Young People. Overarching Principles and Offence Specific Guidelines for Sexual Offences and Robbery. Definitive Guidelines. London: Sentencing Council.

Smith, R. (2005) Welfare versus justice - Again! Youth Justice, 5(1): 3-16.

Smith, R. (2014) Reinventing Diversion. Youth Justice, 14 (2): 109-121.

Smith, R. (2016) Youth Justice: Ideas Policy Practice. Abingdon: Routledge.

Smith, R. (2017) Diversion in Youth Justice. Abingdon: Routledge.

Smith, R. and Gray, P. (2018) The changing shape of youth justice: Models of practice. Criminology and Criminal Justice, Online First.

Solomon, E. and Garside, R. (2008) Ten Years of Labour's Youth Justice Reforms: An Independent Audit. London: Centre for Crime and Justice Studies, Kings College London.

Sutherland, A. (2009) The Scaled Approach in youth justice. Fools rush in. Youth Justice, 9(1): 44-60.

Taylor, C. (2016) Review of the Youth Justice System in England and Wales. London: Ministry of Justice. 
Taylor, R., Evans, J., Stuart-Hamilton, I., Roderique-Davies, G., Pierpoint, H. and Bartlett, H. (2014) A Review of the Speech, Language and Communication Needs of Young People from Wales in the Youth Justice System. Treforest: University of South Wales.

UNCRC (1989) United Nations Convention on the Rights of the Child 1989. Geneva: United Nations.

Wacquant, L. (2009) Punishing the Poor: The Neoliberal Government of Social Insecurity. Durham and London: Duke University Press.

Welsh Government and Youth Justice Board (2014) Children and Young People First. Cardiff: Welsh Government/YJB.

Youth Justice Board (2013) Assessment and Planning Interventions Framework - AssetPlus. Model Document. London: YJB.

Youth Justice Board (2018) Proposed definition of 'Children First, Offenders Second'. Board Information Paper. London: YJB.

Youth Justice Board (2018a) Annual report and accounts. London: YJB.

Youth Justice Board (2018b) Revised National Standards for children in the youth justice system. London: YJB.

Youth Justice Board (2019) Standards for Children the Youth Justice System. London: YJB.

Youth Justice Board and Ministry of Justice (2017) Youth Justice Statistics: 2015 to 2016. London: YJB/MoJ.

Youth Justice Board and Ministry of Justice (2018) Youth Justice Statistics: 2016 to 2017. London: YJB/MoJ.

Youth Justice Board and Ministry of Justice (2019) Youth Justice Statistics: 2017 to 2018. London: YJB/MoJ. 